\title{
Efektivitas program pelatihan pengolahan hidangan appetizer and dessert pada siswa SMK Pratama Widhya Mandala
}

\author{
I Wayan Suryanto *, Ni Made Erpia Ordani Astuti, I Gusti Ayu Agung Sinta Diarini \\ Universitas Dhyana Pura. Jl. Raya Padang Luwih. Br. Tegaljaya, Dalung, Kuta. Bali. 80361. \\ *Corresponding author. Email: suryanto@undhirabali.ac.id
}

Received: 6 June 2020; Revised: 7 October 2020; Accepted: 9 October 2020

\begin{abstract}
Abstrak: Penelitian ini bertujuan untuk mengetahui implementasi program Pelatihan Pengolahan Hidangan Appetizer and Dessert untuk mengembangkan minat berwirausaha dan hasil belajar siswa pada Pelatihan Pengolahan Hidangan Appetizer and Dessert SMK Pratama Widhya Mandala. Penelitian ini menggunakan penelitian evaluasi dengan pendekatan kuantitatif. Subjek penelitian adalah siswa kelas XI Jasa Boga SMK Pratama Widhya Mandala. Pengumpulan data menggunakan metode angket berupa instrument hasil belajar siswa dan data penunjang kualitatif yang diperoleh melalui observasi dan wawancara. Tehnik analisis data dengan mencari rerata hasil pre-test pos-test dan menarik kesimpulan analisis keefektivan menggunakan uji beda rata-rata dengan t-test. Hasil penelitian menunjukkan pelatihan minat berwirausaha dalam pengolahan hidangan Appetezer and Dessert khususnya pembuatan Macaroni Schotel dan Roti Kukus Gula Merah medapatkan perhatian sangat baik terlihat dari antusias dan semangat siswa dalam mengikuti kegiatan. Kemampuan siswa dalam Pengolahan Hidangan Appetezer and Dessert berkembang sangat baik disertai minat berwirausaha siswa dengan rerata hasil pos-test berada pada katagori katogori sangat baik.
\end{abstract}

Kata Kunci: pengolahan Appetezer And Dessert, minat berwirausaha, hasil belajar

\section{The effectiveness of the appetizer and dessert dish processing training program for Students of SMK Pratama Widhya Mandala}

Abstract: This study aims to determine the implementation of the Appetizer and Dessert Dish Processing Training program to develop entrepreneurial interest and student learning outcomes of SMK Pratama Widhya Mandala. This research uses evaluation research with qualitative and quantitative approaches. The research subjects were students of class XI Catering Services at SMK Pratama Widhya Mandala. Data collection using the method of observation, interviews, tests. Data analysis techniques by looking for the mean results of the pre-test post-test and interesting. The results showed that training in entrepreneurial interest in the processing of Appetizer and Dessert dishes, especially the making of Macaroni Schotel and Brown Sugar Steamed Bread, received very good attention, seen from the enthusiasm and enthusiasm of students in participating in the activity. The ability of students in Appetizer and Dessert Dish Processing develops very well with students' interest in entrepreneurship with the average post-test results in the very good category.

Keywords: Appetizer and Dessert processing, interest in entrepreneurship, learning outcomes

How to Cite: Suryanto, I., Astuti, N., \& Diarini, I. (2020). Efektivitas program pelatihan pengolahan hidangan appetizer and dessert pada siswa SMK Pratama Widhya Mandala. JPPM (Jurnal Pendidikan dan Pemberdayaan Masyarakat), 7(2), 159-171. doi:https://doi.org/10.21831/jppm.v7i2.32235

\section{PENDAHULUAN}

SMK Pratama Widhya Mandala beralamat di Dawas, Tibu Beneng, Kuta Utara, Badung, merupakan Sekolah Menengah Kejuruan Pariwisata yang berupaya maksimal memberikan pelayanan yang terbaik kepada masyarakat melalui pendidikan, semakin ketetnya persaingan 
JPPM (Jurnal Pendidikan dan Pemberdayaan Masyarakat), 7 (2), 2020 - 160

I Wayan Suryanto, Ni Made Erpia Ordani Astuti, I Gusti Ayu Agung Sinta Diarini

sekolah-sekolah SMK swasta untuk merebut perhatian dan kepercayaan masyarakat menuntut setiap sekolah untuk terus melakukan inovasi perbaikan kualitas sarana dan prasarana serta kualitas pembelajaran sesuai dengan kebaharuan teknologi, dan informasi yang terkini. Keberhasilan lembaga pendidikan SMK dalam mencetak tenaga-tenaga terampil yang siap dipakai dapat dilihat dari sejauh mana siswa lulusannya mampu terserap bekerja disektor usaha dan industry, serta kemampuan tenaga lulusannya untuk ikut serta dalam persaingan dunia usaha dengan mendirikan usaha sendiri atau menjadi seorang wirausaha mandiri. Kualitas lulusan yang kompeten, siap pakai dalam industry pariwisata baik itu bidang Akomodasi Perhotelan (bidang Kantor Depan dan Tata Graha), Jasa Boga dan Tata Hidang, sangat menentukan keberhasilan sebuah lembaga pendidikan yang berkonsentrasi pada bidang pariwisata. SMK Pratama Widhya Mandala berupaya maksimal memberikan pendidikan dan latihan dengan menyeimbangkan antara teori dan praktek dengan berbagai pendekatan, metode dan model pembelajaran yang tepat agar tujuan pembelajaran tercapai dengan cepat.

Dalam dunia usaha pariwisata khususya bidang perhotelan, Food and Beverage Departmen merupakan salah satu bagian departemen yang memiliki peran yang sangat penting dalam hal menyiapkan berbagai jenis hidangan dari hidangan pembuka, sup, hidangan utama dan hidangan penutup. Food and Beverage Departmen berperan penting sebagai sumber pendapatan terbanyak kedua bagi hotel dalam penjualan makanan dan minuman. Untuk dapat menghasilkan hidangan yang menarik, enak dan juga aman dikonsumsi, SMK Pratama Widya Mandala mendidik siswa jurusan jasa boga dengan mengaplikasikan teori dengan praktik industri disekolah yang mengacu pada perkembangan kebutuhan industri saat ini, dengan harapan siswa nantinya menjadi seorang juru masak (chef) yang profesional saat bekerja di pariwisaata ataupun jika mereka memutuskan untuk berwirausah.

Program kewirausahaan merupakan salah satu cara untuk meningkatkan kualitas kehidupan masyarakat melalui pemberdayaan dengan berbagai program yang memfasilitasi masyarakat untuk melek dalam berbagai bidang (Pamungkas \& Fauziah, 2014). Kewirausahan memegang peranan sangat penting dan berpengaruh jangka panjang dalam meningkatkan kesejahtraan setelah terjun dalam kehidupan masyarakat. Kesejahtraan hidupnya membaik setelah berwirausaha di bidangnya masing-masing dan usaha yang dijalankanya memberikan penghasilan yang lebih baik dari sebelumnya (Wijayanto \& Prasetyo, 2018). Pendidikan kewirausahan menjadi sangat penting bukan saja pada siswa tetapi juga pada masyarakat luas sebagai kecakapan hidup dan meningkatkan kesejahtraan masyarakat.

Melalui pelatihan, diharapkan mampu menemukan permasalahan dan mencari jalan keluar terbaik untuk mengatasi kesulitan belajar yang dialami siswa. Semangat dan antusias siswa dalam mengikuti pembelajaran di SMK Pratama Widya Mandala sangat bagus, sebagian besar siswa yang belajar di sekolah ini memiliki keinginan untuk bisa bekerja di sektor pariwisata, hal ini perlu didukung dengan ketersediaan sarana prasarana yang memadai. Sarana prasarana sangat penting untuk keberhasilan program disamping itu narasumber dan fasilitator yang bagus sangat menentukan keberhasilan tindakan (Atsnan et al., 2020; Pamungkas \& Fauziah, 2014). Siswa belum memiliki pandangan dan keinginan bagaimana mengimplementasikan pengetahuannya dalam usaha mandiri, belum memiliki keberanian dan kemauan berwirausaha. Untuk mengatasinya diperlukan sebuah pelatihan yang berorientasi pada masalah dengan praktek membuat produk yang memiliki peluang usaha, kegiatan ini diharapkan bisa membangkitkan minat siswa untuk berwirausaha. Suryanto et al. (2019) dalam penelitian tentang pengembangan model project-based learning berbasis lesson study untuk meningkatkan minat berwirausaha, hasil belajar, dan kreativitas mahasiswa menyatakan; penilaian minat berwirausaha menunjukkan terjadi peningkatan tertinggi sebesar $15,7 \%$ pada indikator Kepercayaan Diri yaitu dari $80 \%$ pada siklus I meningkat menjadi 95,7\% pada siklus II. Peningkatan tertinggi yang kedua terjadi pada indikator Keberhasilan Karena Hasil Dari Kerja Keras Sendiri sebesar $14,9 \%$ yaitu dari $80,4 \%$ pada siklus I meningkat menjadi 95,3\% pada siklus II. Peningkatan tertinggi yang ketiga terjadi pada indikator Hasil Bukan Keberuntungan sebesar 10,2\% yaitu dari $80 \%$ pada siklus I meningkat menjadi 90,2\% pada siklus II. Peningkatan selanjutnya 
JPPM (Jurnal Pendidikan dan Pemberdayaan Masyarakat), 7 (2), 2020 - 161

I Wayan Suryanto, Ni Made Erpia Ordani Astuti, I Gusti Ayu Agung Sinta Diarini

terjadi pada indikator Yakin akan hasil dari kemampuan sendiri 9,5\%, selanjutnya Memiliki Kematangan mental dalam memulai usaha 9,4\%, Kepemimpinan tergantung kemampuan sendiri 8,3\%, Mampu memimpinan SDM 2,8\%, hal ini menunjukkan minat berwirausaha bisa dikembangkan melalui pendidikan dan pelatihan.

Menggalakkan budaya kewirausahaan dalam masyarakat akan mampu membuka lapangan pekerjaan sehingga penggangguran dan kemiskinan dapat dihindari (Wijayanto \& Prasetyo, 2018). Dalam pembelajaran siswa memerlukan seorang guru yang tidak hanya menguasai materi ajar tetapi mampu menyajikannya dengan berbagai cara yang menarik dalam suasana pembelajaran yang menyenangkan. Pemanfaatan pasilitas sarana prasarana sekolah belum maksimal dalam proses pembelajaran, diperlukan suatu rancangan pembelajaran yang baik agar semua pasilitas yang dimiliki mampu maksimal meningkatkan kualitas pembelajaran.

Kesiapan siswa dalam menjalankan usaha didukung oleh beberapa factor diantaranya; (1) motivasi dan kesungguhan dalam berusaha; (2) perencanaan (promosi dan strategi pemasangan harga) dan pendampingan usaha; (3) kemampuan mengenal peluang, kesempatan, dan kompetitor (pesaing bisnis); (4) lokasi usaha; (5) pengawasan peralatan (Ikhsan, 2017). Beberapa factor tersebut perlu dilatih dan disiapkan dengan baik disertai dengan penguasaan pengetahuan yang memadai. Sebelum siswa terjun dalam industry pariwisata, salah satu pengetahuan siswa SMK pariwisata jurusan jasa boga yang wajib dikuasai adalah pengetahuan tentang mempersiapkan hidangan pembuka (Appetezer), hidangan utama (main couse) dan hidangan penutup (Dessert). Begitu banyak tempat praktek siswa yang memiliki ciri khas berbeda-beda untuk setiap pengolahan dan penyajian makanan, sementara di sekolah waktu yang digunakan untuk kegiatan praktek belum cukup untuk melatih semua masakan di dunia industri, disemamping itu beberapa set menu yang sering dipraktekkan mengacu pada buku pedoman yang dipakai disekolah. Pada saat ini proses pembelajaran siswa kelas XI sudah sampai pada materi dry practice, dan praktek dasar untuk pengolahan/pembuatan kue Indonesia.

Untuk menambah dan melengkapi ketrampilan siswa dalam pengolahan dan penyajian makanan Appetezer and Dessert, dilakukan dengan cara memberikan tambahan pengetahuan yang belum didapatkan disekolah tetapi pengetahuan menu tersebut sering dipakai oleh banyak dunia industri sebagai menu utama ataupun hidangan khusus pada setiap kegiatan tertentu. Tren Penataan Meja Makan dan Pelayanan makanan dan minuman di Restoran yang sedang marak berkembang di dunia industri masa kini adalah Teknik Fusion Food dimana makanan diolah dan ditampilkan secara fantastik sehingga seolah-olah makanan adalah merupakan suatu barang/benda yang tidak untuk dinikmati oleh indera pengecap tetapi merupakan suatu barang seni yang hanya untuk dinikmati oleh indera penglihatan saja (Direktorat Pembinaan SMK, 2013).

Pengolahan dan penyajian makanan adalah mengolah atau memasak dengan bahan, teknik, penyajian dan menu negara continental (Eropa dan Amerika). Hidangan kontinental terdiri dari 2 yaitu hidangan klasik dan hidangan modern. Ciri khas makanan kontinental adalah lebih cenderung banyak lauk pauk hewai yang disertai makanan pokok seperti kentang, pasta atau roti serta sayur pada penghidangan. Pada umumnya hidangan yang biasa disajikan adalah appetizer, soup, main course, dan dessert. Pengolahan dan penyajian merupakan komponen mata pelajaran keahlian produktif. Mata pelajaran produktif merupakan mata diklat yang berfungsi untuk membekali peserta didik dalam bidang kejuruan yang dipilih, secara spesifik sesuai dengan bidang keahlian. Mata pelajararan Pengolahan dan Penyajian Makanan Kontinental yang diberikan kepada peserta didik jurusan Jasa Boga (Budiningsih, 2017).

Penguasaan siswa dalam setiap kompetensi dievaluasi dalam proses uji kompetensi yang harus dilalui sebagai tolak ukur kompetensi siswa setelah menempuh pendidikan SMK. (Kurikulum SMK, 2004). Pengolahan dan penyajian makanan merupakan salah satu pendukung keberhasilan siswa dalam mengikuti uji kompetensi. Beberapa menu pengolahan hidangan Appetezer and Dessert yang di ajarkan belum dikuasai dengan baik oleh siswa sehingga dipandang perlu untuk memberikan tambahan pengetahuan dan ketrampilan. kegiatan pelatihan pengolahan hidangan Appetezer and Dessert khususnya Macaroni Schotel dan Roti Kukus Gula 
JPPM (Jurnal Pendidikan dan Pemberdayaan Masyarakat), 7 (2), 2020 - 162

I Wayan Suryanto, Ni Made Erpia Ordani Astuti, I Gusti Ayu Agung Sinta Diarini

Merah, kegiatan ini akan memberikan tambahan pengetahuan pada siswa sebelum mereka melakukan praktek kerja lapangan. Materi pelatihan yang diberikan merupakan materi dasar yang berkaitan erat dengan dunia industri perhotelan khususnya bidang Appetezer And Dessert, materi ini juga mampu menambahkan kompetensi siswa pada tahapan persiapan, pengolahan, dan penyajian makanan penutup (Maulani et al., 2016) untuk memperkuat pemahaman siswa disaat praktek akan dilanjutkan dengan memberikan pelatihan tentang kewirausahaan agar siswa nantinya memiliki minat untuk berwirausaha. Dari pelatihan ini diharapkan peserta dapat menyerap ilmu dan mengaplikasikan di bidang industri atau dunia kerja dan bermaanfaat juga bagi siswa setelah selesai menempuh pendidikan di SMK Pratama Widya Mandala. Hal inilah yang menarik penulis untuk mengulas lebih dalam tentang efektivitas program pelatihan pengolahan hidangan appetizer and dessert khususnya pada pembuatan macaroni schotel dan roti kukus gula merah pada siswa SMK Pratama Widhya Mandala

\section{METODE}

Penelitian ini menggunakan penelitian evaluasi dengan pendekatan kuantitatif. Waktu pelasanaan penelitian padabulan Mei-Juni 2019, dengan tempat penelitian di SMK Pratama Widhya Mandala yang beralamat di Dawas, Tibu Beneng, Kuta Utara, Badung, Bali.

Subjek penelitian adalah siswa kelas XI Jasa Boga I SMK Pratama Widhya Mandala, yang terlibat dalam pelaksanaan Pelatihan Pengolahan Hidangan Appetezer and Dessert untuk mengembangkan minat berwirausaha dan hasil belajar siswa

Metode Pengumpulan data menggunakan metode angket berupa instrument test hasil belajar siswa dan didukung dengan data penunjang kualitatif yang diperoleh melalui observasi dan wawancara. Tehnik analisis data dengan analisis kuantitatif dengan mencari rerata hasil pretest pos-test yang selanjutnya dianalisis menggunakan uji-t untuk menarik kesimpulan.

\section{HASIL DAN PEMBAHASAN}

Pelatihan ini merupakan bagian dari pelaksanaan Tridharma Perguruan Tinggi, pelatihan ini akan membangkitkan niat berwirausaha siswa yang dilanjutkan dengan memberikan ketrampilan berwirausaha khususya dalam pengolahan dan penyajian Hidangan Appetizer and Dessert pada pembuatan Macaroni Schotel dan Roti Kukus Gula Merah. Kegiatan ini diawali dengan sambutan dari kepala SMK Pratama Widhya Mandala sekaligus membuka acara pelatihan. Dalam sambutannya kepala SMK Pratama Widhya Mandala mengucapkan terimakasih atas terselenggaranya acara pelatihan ini dan menguraikan secara singkat tentang keberadaan SMK Pratama Widhya Mandala, capaian keberhasilan yang telah diperoleh dan beberapa kendala yang sedang dihadapi dalam proses pembelajaran untuk mempersiapkan peserta didik untuk menjadi tenaga terampil dan kompeten setelah lulus nanti. Kepala SMK Pratama Widhya Mandala juga menegaskan saat ini ketersediaan tenaga kerja menjadi persoalan yang dihadapi oleh lulusan SMK, ketimpangan antara ketersediaan lapangan kerja dan tenaga kerja yang kompeten berakibat pada meningkatnya jumlah pengangguran yang berdampak pada ekonomi dalam masyarakat. Dengan pelatihan ini diharapkan mampu membangkitkan minat berwirausaha dan sekaligus melatih ketrampilan siswa dalam membuat produk-produk kreatif kewirausahaan sebagai bekal ketrampilan yang bisa digunakan setelah lulus nantinya. Kepala SMK Pratama Widhya Mandala menekan pada pembentukan dan penguatan ketrampilan yang menjadi kemampuan dasar saudara dalam berwirausaha oleh sebab itu kepala sekolah berpesan agar peserta didiknya bersungguh-sungguh secara tekun dalam mengikuti pelatihan ini karena kesempatan untuk mengikuti pelatihan seperti ini jarang didapatkan. Pada kesempatan yang sama Kepala SMK Pratama Widhya Mandala juga mengucapkan terimakasi atas terselenggaranya pelatihan ini dan mengharapkan kegiatan pelatihan selanjutnya untuk menambah pengetahuan dan ketrampilan siswa agar mereka lebih siap dalam berkompotisi dalam dunia kerja dan mampu serta memiliki kesiapan mental dalam berwirausaha. 
JPPM (Jurnal Pendidikan dan Pemberdayaan Masyarakat), 7 (2), 2020 - 163

I Wayan Suryanto, Ni Made Erpia Ordani Astuti, I Gusti Ayu Agung Sinta Diarini

Pelatihan selanjutnya diawali dengan arahan dari fasilitator tentang pelaksanaan kegiatan. Pelatihan ini merupakan bagian dari pelaksanaan Tridharma Perguruan Tinggi dalam bentuk pengabdian masyarakat. Pelatihan ini akan membangkitkan minat siswa untuk berwirausaha, dengan memberikan pengetahuan, memotivasi dan menguatkan keyakinan siswa. Pelatihan minat berwirausaha mencakup penguatan aspek; (1) Self-efficacy yang penekananya tentang, kepercayaan diri, memimpinan sumber daya manusia, Kematangan mental dalam memulai usaha, keyakinan yang teguh dalam keberhasilan usaha. (2) Locus of control yang mencakup; yakin bahwa segala hasil yang telah dicapai karena kemampuan diri sendiri, kepemimpinan sangat bergantung pada kemampuan, keberhasilan yang terjadi karena hasil dari kerja keras sendiri, sesuatu yang selama ini dicapai bukan keberuntungan (Suryanto et al., 2019). Pelatihan mengembangkan minat berwirausaha, dilakukan didalam kelas dengan suasana pembelajaran yang sangat menyenangkan dengan fokus materi tentang pembangkitan dan penguatan minat berwirausaha. Kegiatan ini diawali dengan memberikan tes awal dengan tujuan untuk mengukur kemampuan siswa sebelum kegiatan pelatian. Berdasarkan hasil evaluasi pre-test minat berwirausaha rerata kemampuan siswa berada pada katagori cukup, beberapa hal yang menjadi pusat perhatian sebagai kajian minat berwirausaha berdasarkan indikator yang dinilai, dan diurut dari yang paling tinggi pengaruhnya adalah; siswa sudah memiliki kepercayaan diri yang baik, memiliki kematangan mental berwirausaha dengan katagori baik, memiliki keyakinan keberhasilan karena kerja keras sendiri dengan katagori baik. untuk selengkapnya data pre-test disajikan dalam Gambar 1.

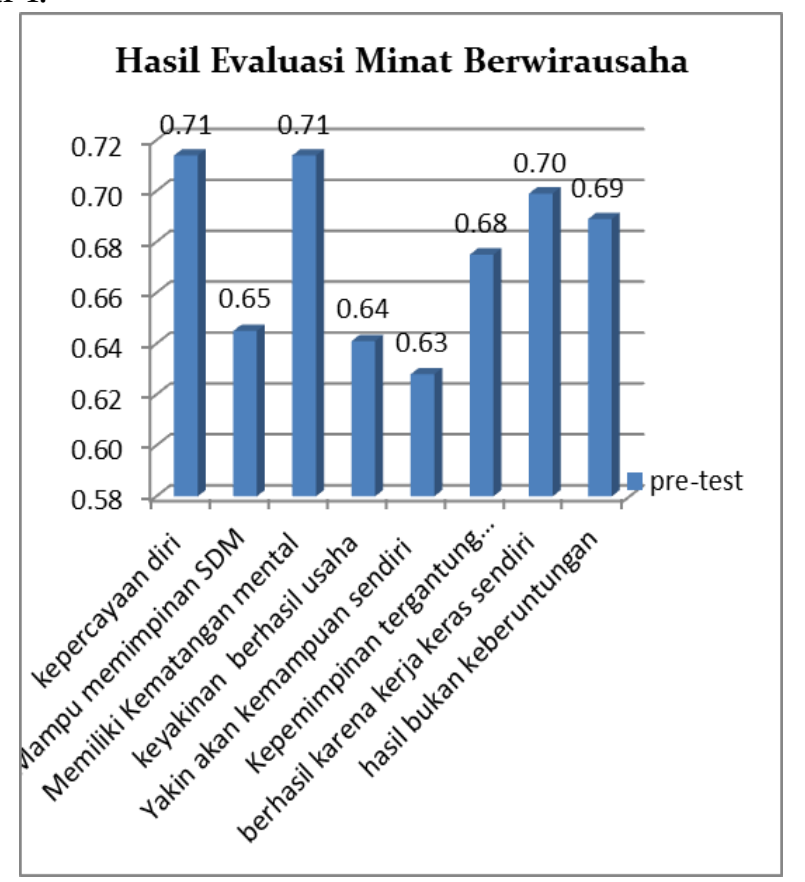

Gambar 1. Hasil Evaluasi Pre-test Minat Berwirausaha

Dari hasil pre-test ini menunjukkan siswa sudah memiliki kesiapan mental yang cukup baik untuk berwirausaha. Beberapa hal yang perlu menjadi perhatian dalam kegiatan ini adalah menumbuhkan kepercayaan diri siswa tentang hasil yang akan didapatkan, yakin akan kemampuan sendiri, keberhasilan dalam berusaha, dan meningkatkan kemampuan memimpin sumber daya manusia. Meningkatkan semangat kewirausahaan sosial pada setiap individu yang ada di masyarakat, terutama kaum muda sebagai tulang punggung bangsa dalam pembangunan di segala bidang dan stabilitas nasional (Utomo, 2015).

Berdasarkan hasil evaluasi pre-test kegiatan pelatihan dilakukan dengan memperhatikan kekuatan dan kelemahan yang dimiliki siswa pada setiap indikatornya. Dengan penyajian materi yang menarik siswa sangat bersemangat dan antusias mengikuti kegiatan. dengan menyelipkan beberapa permainan tentang kepemimpinan membuat kegiatan ini menjadi sangat menyenang- 
JPPM (Jurnal Pendidikan dan Pemberdayaan Masyarakat), 7 (2), 2020 - 164

I Wayan Suryanto, Ni Made Erpia Ordani Astuti, I Gusti Ayu Agung Sinta Diarini

kan. Hasil dari pelatihan ini setelah dilakukan pos-test menunjukkan peningkatan dari evaluasi pre-test sebelumnya sebesar $18,3 \%$. Rerata hasil evaluasi minat berwirausaha siswa berada pada katagori sangat baik yang sisajikan dalam Gambar 2.

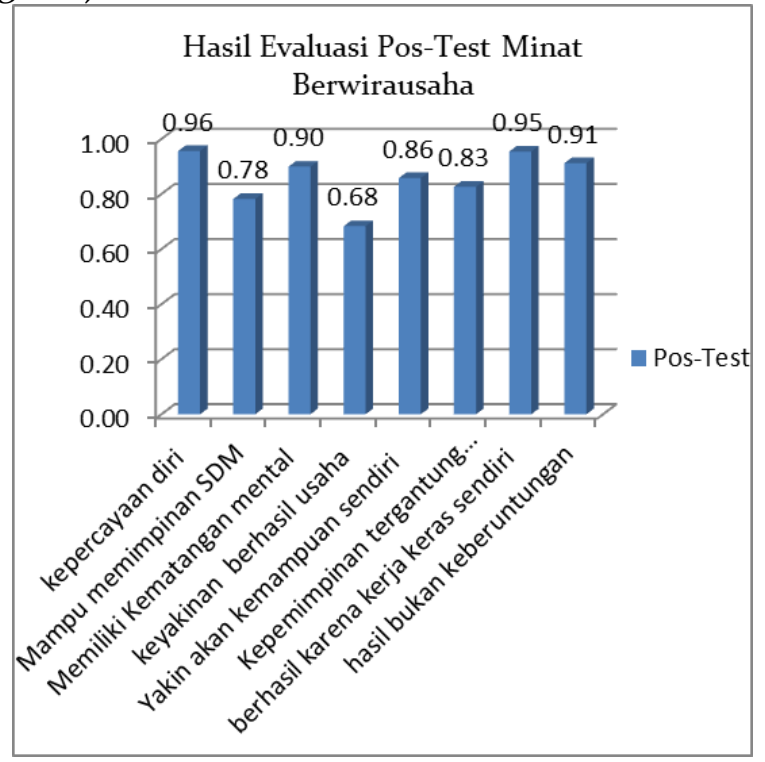

Gambar 2. Hasil Evaluasi Pos-test Minat Berwirausaha

Pada setiap aspek penilaian minat berwirausaha mengalami peningkatan yang sangat baik, satu aspek penilaian yang masih perlu ditingkatkan adalah keyakinan akan berhasilnya usaha. Hal ini menunjukan kurangnya pengetahuan tentang analisis usaha dan resiko yang menjadi perhatian untuk kegiatan selanjutnya.

Pelatihan pengolahan Hidangan Appetezer and Dessert khususnya pembuatan Macaroni Schotel dan Roti Kukus Gula Merah, dilakukan setelah kegiatan menumbuhkan minat berwirausaha, pelatihan ini juga diawali dengan memberikan pre-test yang berhubungan dengan hasil belajar penguasaan materi pengolahan dan penyajian makanan yang mencakup aspek kognitif, afektif, dan psikomotor (Sudjana, 2002). Evaluasi kegiatan dibatasi pada penilaian hasil belajar Hidangan Appetezer and Dessert khususnya pembuatan Macaroni Schotel dan Roti Kukus Gula Merah sampai dengan cara penyajian makanan. Hasil pre-test menunjukkan keseluruhan penilaian hasil belajar yang mencakup aspek kognitif, afektif dan psikomotor berada pada katagori baik. Pengetahuan dasar tentang Appetezer and Dessert sudah dikuasai dengan baik sehingga memudahkan tim untuk memberikan materi tambahan tentang pembuatan Macaroni Schotel dan Roti Kukus Gula Merah.

Pelatihan ini diawali dengan penyampaian materi tehnik pengolahan yang dilanjutkan dengan demonstrasi pembuatan Macaroni Schotel dan Roti Kukus Gula Merah. Kegiatan selanjutnya, melakukan pendampingan yang dibantu oleh mahasiswa, diawali dengan membagikan resipi, siswa didampingi pemateri mempersiapkan bahan sesuai dengan kebutuhan dan takaran dalam resipi, kemudian mulai mengolahnya menjadi Macaroni Schotel dan Roti Kukus Gula Merah sesuai dengan petunjuk dan arahan pemateri yang didampingi oleh mahasiswa. Proses kegiatan ini berjalan dengan sangat baik, agak sedikit gaduh karena semua siswa sibuk bekerja maksimal, berusaha dengan baik agar hasilnya memuaskan. Sambil menunggu matang kegiatan dilanjutkan dengan pemberian materi tehnik penyajian dan pengkemasan produk Macaroni Schotel dan Roti Kukus Gula Merah. Dengan posisi setengah lingkaran siswa mendengar dan memperhatikan tehnik penyajian dan pengkemasan yang didemonstrasikan oleh pemateri dengan baik. Setelah Macaroni Schotel dan Roti Kukus Gula Merah matang siswa mempraktikkan penyajian makanan dengan didampingi mahasiswa, beberapa sentuhan kreatifitas yang berbeda pada setiap sajian makanan telah mampu diperlihatkan dengan baik oleh siswa. Secara keseluruhan pelaksanaan kegiatan pelatihan pengolahan dan penyajian Macaroni Schotel dan Roti Kukus Gula Merah ini berjalan sangat baik, siswa begitu antusias dan bersemangat dalam 
JPPM (Jurnal Pendidikan dan Pemberdayaan Masyarakat), 7 (2), 2020 - 165

I Wayan Suryanto, Ni Made Erpia Ordani Astuti, I Gusti Ayu Agung Sinta Diarini

mengerjakan tugas-tugasnya, setiap tahapan diikuti dan dikerjakan dengan baik. Dengan pendampingan oleh pemateri yang dibantu mahasiswa, hampir tidak terjadi kesalahan dalam proses belajarnya.

Hasil evaluasi belajar pos-test pengolahan dan penyajian hidangan Appetezer and Dessert khususnya pembuatan Macaroni Schotel dan Roti Kukus Gula Merah mengalami peningkatan sebesar $17 \%$ dari hasil pada pre-test dengan katagori sangat baik. Untuk lebih jelas peningkatan hasil evaluasi belajar pengolahan Hidangan Appetezer and Dessert khususnya pembuatan Macaroni Schotel dan Roti Kukus Gula Merah, disajikan dalam Tabel 1.

Table 1. Hasil Evaluasi Belajar Pengolahan dan Penyajian Hidangan Appetezer and Dessert Khususnya Pembuatan Macaroni Schotel Dan Roti Kukus Gula Merah

\begin{tabular}{ccc}
\hline Hasil Evaluasi Belajar & Pre-Test & Pos-Test \\
\hline Aspek kognitif & 0.76 & 0.90 \\
Aspek afektif & 0.71 & 0.90 \\
Aspek psikomotor & 0.73 & 0.91 \\
Rerata Hasil Belajar & 0.73 & 0.90 \\
\hline
\end{tabular}

Langkah selanjutnya adalah melakukan evaluasi terhadap program pelatihan secara keseluruhan untuk mengetahui pengaruh pelatihan minat berwirausaha dan pengolahan Hidangan Appetezer and Dessert khususnya pembuatan Macaroni Schotel dan Roti Kukus Gula Merah, dengan menggunakan uji-t.

Tabel 2. Hasil analisis paired sample test minat berwirausaha dan hasil belajar

\begin{tabular}{|c|c|c|c|c|c|c|c|c|c|}
\hline & & & & $\begin{array}{l}\text { ired Samples } \\
\text { ed Difference }\end{array}$ & Test & & & & \\
\hline & & Mean & $\begin{array}{c}\text { Std. } \\
\text { Deviation }\end{array}$ & $\begin{array}{l}\text { Std. Error } \\
\text { Mean }\end{array}$ & $\begin{array}{r}95 \% \mathrm{Cc} \\
\text { Interv } \\
\text { Diff }\end{array}$ & $\begin{array}{l}\text { nfidence } \\
\text { l of the } \\
\text { rence }\end{array}$ & $\mathrm{t}$ & df & $\begin{array}{l}\text { Sig. (2- } \\
\text { tailed) }\end{array}$ \\
\hline & & & & & Lower & Upper & & & \\
\hline $\begin{array}{l}\text { Pair } \\
1\end{array}$ & $\begin{array}{l}\text { Pretest Minat } \\
\text { berwirausaha - } \\
\text { Posttest Minat } \\
\text { berwirausaha }\end{array}$ & -21.902 & 15.543 & 2.427 & -26.808 & -16.996 & -9.023 & 40 & .000 \\
\hline $\begin{array}{l}\text { Pair } \\
2\end{array}$ & $\begin{array}{l}\text { Pretest Hasil } \\
\text { Belajar - } \\
\text { Posttest Hasil } \\
\text { Belajar }\end{array}$ & -8.537 & $7 \cdot 376$ & 1.152 & -10.865 & -6.208 & -7.411 & 40 & .000 \\
\hline
\end{tabular}

Berdasarkan hasil uji-t menggunakan Paired Samples Test menunjukkan signifikansi 2tailed sebesar o,ooo lebih kecil dari o,05 yang menunjukknan terdapat pengaruh yang bermakna pelatihan minat berwirausaha dan pengolahan Hidangan Appetezer and Dessert khususnya pembuatan Macaroni Schotel dan Roti Kukus Gula Merah terhadap peningkatan minat siswa dalam berwirausaha dan peningkatan kompetensi siswa dalam pengolahan dan penyajian hidangan Appetezir and Dessert. Untuk lebih jelas peningkatan tentang minat berwirausaha dan hasil belajar pengolahan dan penyajian Macaroni Schotel dan Roti Kukus Gula Merah, dalam setiap aspek indikator penilaian disajikan dalam Gambar 3.

Secara keseluruhan jika hasil rerata evaluasi minat berwirausaha dan hasil belajar siswa direratakan, maka hasil Rekapitulasi rerata minat berwirausaha dan hasil belajar siswa pada tahap pre-test sebesar $69 \%$ dengan katagori cukup, meningkat pada hasil evaluasi pos-test sebesar $87 \%$ atau berada pada katagori sangat baik. Untuk lebih jelas keseluruhan hasil rerata evaluasi disajikan dalam gambar Gambar 4.

Hasil penelitian menunjukkan bahwa semakin meningkatnya self-efficacy dan locus of control yang dimiliki siswa maka semakin meningkat pula niat siswa untuk ber wirausaha. Hal ini sejalan dengan penelitian Adnyana dan Purnami (2016) yang menyatakan bahwa pendidikan kewirausahaan, self-efficacy dan locus of control berpengaruh positif dan signifikan pada niat 
JPPM (Jurnal Pendidikan dan Pemberdayaan Masyarakat), 7 (2), 2020 - 166

I Wayan Suryanto, Ni Made Erpia Ordani Astuti, I Gusti Ayu Agung Sinta Diarini

berwirausaha mahasiswa. Keberhasilan masa depan remaja disebabkan oleh self-efficacy dan usulkan sebagai model pengembangan generasi di masa depan. (Zainualdin et al., 2019). Meningkatkan minat berwirausaha siswa adalah salah satu cara untuk mengerakkan pembangunan nasional dengan menambah jumlah wirausahawan. Pembangkitan niat berwirausaha bagi siswa merupakan usaha melatih siswa agar memiliki semangat untuk berusaha sebagai bekal keterampilan yang sangat bermanfaat bagi mereka setelah lulus nanti. Kodden (2020) menyatakan bahwa bakat super tidak ada, tetapi pengaruh dari self-efficacy sikap Profesional dengan kepribadian yang tepat meningkatkan ketrampilan melalui praktek. Menumbuhkan minat berwirausaha bagi siswa SMK sehingga setelah lulus dari SMK tidak lagi berorientasi mencari kerja tapi membuka lapangan pekerjaan. Tumbuhnya lapangan kerja baru dapat membantu pemerintah mengurangi pengangguran dan meningkatkan kesejahteraan masyarakat (Tahirs \& Rambulangi, 2020).

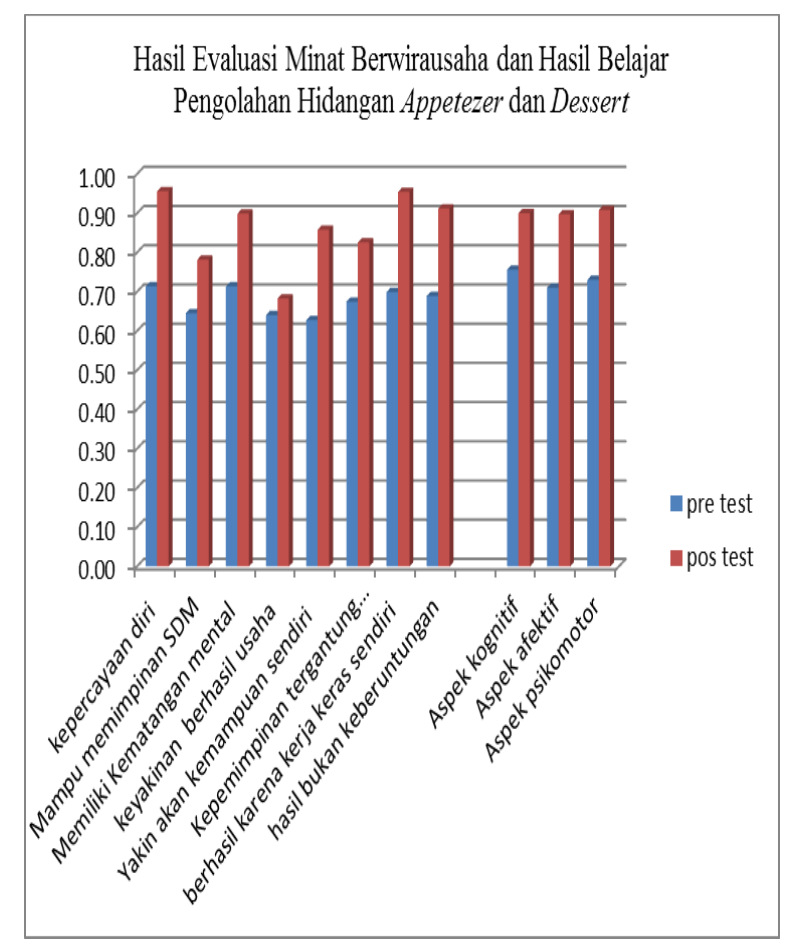

Gambar 3. Evaluasi Minat Berwirausaha dan Hasil Belajar

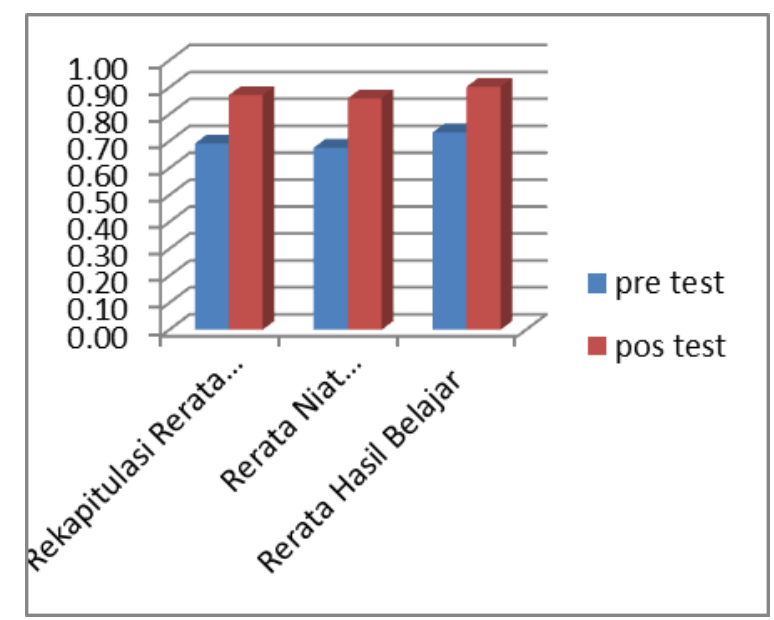

Gambar 4. Rekapitulasi Rerata Hasil Minat Berwirausaha dan Hasil Belajar Siswa

Pelatihan minat kewirausahaan memberikan pengaruh positif terhadap prilaku melalui sikap kewirausahaan dan niat berwirausaha (Sari, 2013). Siswa berusaha bekerja keras ingin menunjukkan hasil kerja yang terbaik, kepercayaan diri mulai berkembang sangat baik dalam 
JPPM (Jurnal Pendidikan dan Pemberdayaan Masyarakat), 7 (2), 2020 - 167

I Wayan Suryanto, Ni Made Erpia Ordani Astuti, I Gusti Ayu Agung Sinta Diarini

setiap tahapan, kematangan mental terbentuk dengan sendirinya melalui hasil karya dalam kegiatan pelatihan. Keberhasilan pelatihan ini sangat didukung oleh suasana pembelajaran yang baik dan lingkungan sekolah dan lingkungan keluarga yang memberikan dukungan sepenuhnya terhadap kegiatan pelatihan. Hal ini sejalan dengan hasil penelitian (Marini \& Hamidah, 2014).

Pelatihan pengembangan minat berwirausaha telah mampu mengembangkan konsep diri peserta didik agar memiliki keyakinan akan usahanya dan keberhasilan dalam kerja bukan merupakan keberuntungan dengan konsep diri yang kuat dan lingkungan belajar yang baik, kematangan mental siswa untuk berwirausaha setelah tamat nanti menjadi lebih kuat. konsep diri dan lingkungan belajar berperan penting dalam mempersiapkan siswa memperoleh pengetahuan, keterampilan, pemahaman, dan kepribadian di lingkungan Sekolah Menengah Kejuruan, untuk kemudian diterapkan di dunia kerja setelah lulus (Tentama \& Jayanti, 2019). Siswa juga mengalami peningkatan pengetahuan dan kemampuan di bidang wirausaha. Dengan demikian siswa dapat mempraktikan ilmu mereka. Siswa yang tergabung pada kegiatan ini juga menginginkan adanya pemantauan, pembinaan dan pengawasan serta evaluasi dari kegiatan yang dilakukan (A. Kurniawan et al., 2020).

Pelatihan pengembangan minat berwirausaha merupakan kegiatan yang bermakna untuk memberikan penguatan tentang penguasaan materi kewirausahaan yang telah diberikan disekolah atau dikenal dengan edupreneurship, yang berusaha untuk membangkitkan potensi yang di miliki peserta didik dengan cara melatih siswa untuk mengembangkan usaha kreatif atau inovatif dengan melihat atau menciptakan peluang dan merealisasikannya menjadi sesuatu yang memiliki nilai tambah baik secara ekonomi maupun social (Mulyatiningsih et al., 2014). Menurut Abdul Rani et al. (2019) lebih banyak simulasi, kasus nyata dan diskusi secara tidak langsung secara tidak langsung dapat menangkap niat dan minat mahasiswa untuk terjun ke dunia wirausaha di masa depan. Keberhasilan sebuah lembaga pendidikan untuk menciptakan output peserta didik yang berkualitas tidak saja mengharumkan nama sekolah dengan prestasi yang diperoleh siswa dalam setiap kompetisi akan tetapi juga mampu meningkatkan kualitas pendidikan secara nasional dan mempercepat tercapainya tujuan pembangunan nasional.

Pembelajaran kewirausahaan di sekolah hendaknya lebih banyak diimplementasikan dengan menggunakan beberapa pendekatan model pembelajaran yang berorientasi pada produk atau projek untuk mengasah dan meningkatkan ketrampilan dan kompetensi siswa. Pelaksanaan pembelajaran berbasis proyek dalam pembelajaran kewirausahaan mampu meningkatkan minat berwirausaha siswa serta meningkatkan hasil belajar kewirausahaan siswa (Darmawan \& Suetjipto, 2016). Pembelajaran berbasis proyek atau masalah juga mampu merubah kebiasaan guru yang mengajar dengan cara konvensional beradaptasi lebih baik dengan pembelajaran berbasis proyek (Odell et al., 2019). Hal ini sangat berpengaruh terhadap keberhasilan peserta didik dalam mencapai tujuan pembelajaran. Penelitian Virtue dan HinnantCrawford (2019) menunjukkan, siswa berpendapat bahwa Pelaksanaan pembelajaran berbasis proyek atau masalah lebih cocok daripada yang lainnya, dimana hasil kerja keras mereka dihargai dengan baik dan setiap proyek yang dikerjakan sangat dekat dengan dunia nyata. Peneliti merekomendasikan penerapan model pembelajaran projek basede learning sebagai model yang cocok digunakan dalam setiap pelatihan dan disekolah menengah untuk mengembangkan pembelajaran.

Pengembangan minat berwirausaha juga perlu diperkuat dengan pemberian materi kewirausahaan yang diimplementasikan dalam metode pembelajaran Teaching factory yaitu pendekatan pembelajaran yang menghadirkan pembelajaran disekolah berbasis industry, dengan tujuan melatih siswa agar terbiasa melakukan kegiatan berbasis industry yang mampu melatih kecakapan dan ketrampilan siswa agar terbiasa mengatasi permasalahan yang sering muncul dalam dunia usaha dan industry. Penerapan model pembelajaran Teaching factory dengan 6M yaitu; Menerima order; Menganalisis order; Menyatakan Kesiapan mengerjakan order; Mengerjakan order; Mengevaluasi produk; Menyerahkan order efektif dalam meningkatkan hasil belajar kewirausahaan yang ditinjau dari segi konteks, input, proses dan produk pada siswa jurusan kria tekstil SMK 6 Pontianak (Asriati, 2018). Implementasin Teaching factory juga 
JPPM (Jurnal Pendidikan dan Pemberdayaan Masyarakat), 7 (2), 2020 - 168

I Wayan Suryanto, Ni Made Erpia Ordani Astuti, I Gusti Ayu Agung Sinta Diarini

meningkatkan kompetensi keahlian siswa agar mampu menjadi pengusaha handal dan bekerja sesuai dengan kompetensi keahliannya. Beberapa komponen Teaching factory yaitu: (1) produk sebagai media untuk memperkenalkan kompetensi, (2) lembaran pekerjaan yang berisi rangkaian dan penilaian kerja sesuai dengan prosedur kerja standar industri, dan (3) mengatur jadwal pembelajaran yang memungkinkan penyampaian soft skill dan keterampilan keras kepada siswa secara optimal (Muttaqien, 2019). Pembelajaran ini diharapkan akan dapat membuat siswa siap bekerja dan memiliki jiwa enterpreneurship, sehingga pengangguran lulusan SMK dapat berkurang dukungan industri berpengaruh terhadap keberhasilan pelaksanaan teaching factory sehingga SMK hendaknya memperkuat kerjasama dengan industri karena dukungan industri memberikan pengaruh terhadap keberhasilan siswa melaksanakan teaching factory (Rizky et al., 2018). Beberapa penelitian yang lain menguatkan bahwa oleh penerapan model pembelajaran teaching factory mampu meningkatkan minat siswa dalam berwirausaha (Diwangkoro \& Soenarto, 2020; Gozali et al., 2018; Handayani et al., 2019; R. Kurniawan, 2018).

Pelatihan pengolahan Hidangan Appetizer and Dessert khususnya pembuatan Macaroni Schotel dan Roti Kukus Gula Merah terhadap peningkatan minat siswa dalam berwirausaha dan peningkatan kompetensi siswa dalam pengolahan dan penyajian hidangan Appetezir and Dessert, mampu meninkatkan kompetensi siswa dari aspek kognitif, efektif dan psikomotor. Persiapan yang baik sebelum pelatihan dimulai yang menyangkut ketersediaan alat, persiapan bahan dan resep serta tehnik pengolahan yang telah didemonstrasikan diawal membuat kegiatan pelatihan berhasil $\mathrm{m}$,encapai tujuan. Sama halnya dengan pendapat dari hasil penelitian Putri (2014) tentang manfaat hasil belajar praktik pembuatan main course dari seafood berkaitan dengan tahap persiapan memegang peranan penting dalam praktek pembuatan main couse. Pengetahuan pengolahan bahan makanan memegang peranan penting untuk mengembangkan pengetahuan dan ketrampilan siswa agar memperoleh hasil yang maksimal. Selajan dengan penelitian Irawati (2014) bahwa pengolahan pada kesiapan uji kompetensi hidangan kontinental yang berada pada kriteria bermanfaat apabila kemampuan pengetahuan siswa mengolah hidangan sesuai dengan teknik yang tepat. Sering melakukan latihan dirumah atau di laboratorium tata boga serta dengan membaca buku yang relevan agar semakin siap untuk menghadapi tes uji kompetensi (Anjani et al., 2016). Keberhasilan yang siswa rasakan pada saat pengolahan makanan Appetizer and Dessert tidak akan bisa terlihat tanpa melewati proses penyajian makanan. Sejalan dengan penelitian (Maulani et al., 2016) siswa merasakan manfaat hasil belajar makanan penutup (dessert) pada tahap penyajian dessert dalam uji level. Sentuhan kreatifitas yang berbeda dalam setiap penyajian makanan menumbuhkan rasa percaya diri dan kebanggaan ketika makanan di sajikan dengan sentuhan seni yang berbeda.

\section{SIMPULAN}

Pendidikan kewirausahaan memegang peranan penting dalam mempersiapkan peserta didik untuk menjadi seorang wirausaha, meskipun mata pelajaran ini telah diberikan pada siswa SMK namun dalam pelaksanaannya masih memerlukan banyak simulasi, yang berorientasi pada kasus nyata dengan berdiskusi, maka secara tidak langsung dapat menangkap niat dan minat siswa untuk terjun ke dunia wirausaha di masa depan.

Keyakinan akan kemampuan sendiri dalam bekerja ataupun keyakinan akan mampu merealisasi semua perencanaan usaha bukan terletak pada kompetensi seseorang, self-efficacy lebih mengarah pada sikap apa yang harus dilakukan, bagaimana cara melakukan, apa yang harus dipelajari untuk mencapai tujuan yang ditetapkan secara berkelanjutan. Sikap inilah yang mendorong mereka untuk menyelesaikan tugas-tugas yang diberikan. Bakat super tidak ada, tetapi pengaruh dari self-efficacy sikap Profesional dengan kepribadian yang tepat akan dapat meningkatkan ketrampilan siswa melalui latihan yang memungkinkan mereka untuk lebih meningkatkan kinerja mereka untuk diri sendiri dan untuk organisasi di masa depan.

Pengembangan pembelajaran di sekolah perlu ditingkatkan untuk meningkatkan kualitas pembelajaran menuju pada kemandirian sekolah untuk mencetak peserta didik yang siap ber- 
JPPM (Jurnal Pendidikan dan Pemberdayaan Masyarakat), 7 (2), 2020 - 169

I Wayan Suryanto, Ni Made Erpia Ordani Astuti, I Gusti Ayu Agung Sinta Diarini

wirausaha dan berani berkompetisi dikehidupan nyata dalam dunia usaha dan industry. Peningkatan kualitas pembelajaran yang diberikan oleh guru harus ditunjang oleh komitmen sekolah dalam menyusun strategi pengembangan kewirausahaan disekolah. Sekolah perlu menjalin kerjasama dengan dunia industry untuk mengetahui perkembangan pasar dan kebutuhan konsumen saat ini, dengan kerjasama yang baik memudahkan siswa untuk melakukan magang diluar sekolah yang mampu meningkatkan penguasaan ketrampilan para siswa.

\section{DAFTAR PUSTAKA}

Abdul Rani, N. S., Sarojani Krishnan, K., Saidun, Z., \& Ahmad, H. (2019). The relationship between entrepreneurship education and entrepreneurial intention of Universiti Kuala Lumpur - Teknoputra Alumni. Humanities E Social Sciences Reviews, 7(1), 147-155. https://doi.org/10.18510/hssr.2019.7118

Adnyana, I. G. L. A., \& Purnami, N. M. (2016). Pengaruh pendidikan kewirausahaan, self efficacy dan locus of control pada niat berwirausaha. E-Jurnal Manajemen, 5(2). https://ojs.unud.ac.id/index.php/Manajemen/article/view/16350

Anjani, R., Juwaedah, A., \& Setiawati, T. (2016). Analisis hasil belajar "mengolah hot and cold appetizer atau salad" sebagai kesiapan tes uji kompetensi makanan kontinental pada siswa SMK Negeri 3 Sukabumi. Media Pendidikan, Gizi, Dan Kuliner, 5(1). https://doi.org/10.17509/boga.v5i1.8448

Asriati, N. (2018). Pengembangan model pembelajaran teaching factory 6M menghadapi revolusi industri keempat di SMK Negeri 6 Pontianak. JURKAMI: Jurnal Pendidikan Ekonomi, 3(2), 70-86. https://doi.org/10.31932/jpe.v3i2.334

Atsnan, M. F., Gazali, R. Y., Maulana, F., \& Fajaruddin, S. (2020). Pengembangan keprofesian berkelanjutan bagi guru-guru di SLB Negeri Martapura. Jurnal Abdimas Mahakam, 4(1), 29-36. https://doi.org/10.24903/jam.v4i1.548

Budiningsih, A. (2017). Pengolahan dan penyajian makanan. Yudhistira.

Darmawan, I., \& Suetjipto, B. E. (2016). The implementation of project base learning to improve entrepreneurrial intention and entrepreneurship learning out come of economics education student. IOSR Journal of Business and Management, 18(10), 98-102.

Direktorat Pembinaan SMK. (2013). Tata hidang-2. bahan ajar kurikulum 2013 sekolah menengah kejuruan program keahlian tata boga. Kementerian Pendidikan Dan Kebudayaan Direktorat Pembinaan Sekolah Menengah Kejuruan.

Diwangkoro, E., \& Soenarto. (2020). Development of teaching factory learning models in vocational schools. Journal of Physics: Conference Series, 1456, 012046.

https://doi.org/10.1088/1742-6596/1456/1/012046

Gozali, G., Dardiri, A., \& Soekopitojo, S. (2018). Penerapan teaching factory jasa boga untuk meningkatkan kompetensi entrepreneur siswa sekolah menengah kejuruan. JSHP: Jurnal Sosial Humaniora Dan Pendidikan, 2(1), 46-50. https://doi.org/10.32487/jshp.v2i1.264

Handayani, S., Azizah, D. N., \& Indahsari, E. L. (2019). The implementation evaluation of teaching factory learning model on APT productive learning at SMK Negeri 2 Subang. 5th UPI International Conference on Technical and Vocational Education and Training (ICTVET 2018), 557-561.

Ikhsan, N. L. (2017). Implementasi program desa vokasi berbasis pelatihan kewirausahan tata boga. JPPM (Jurnal Pendidikan Dan Pemberdayaan Masyarakat), 4(2), 133-145. https://doi.org/10.21831/jppm.v4i2.8047

Kodden, B. (2020). The impact of self-efficacy. In The Art of Sustainable Performance (pp. 3138). https://doi.org/10.1007/978-3-030-46463-9_5

Kurniawan, A., Rahmi, V. A., \& Nata, J. H. (2020). Penguatan” mindset youngpreneurship" pada lingkungan Majelis Dikdasmen PDM di Wilayah Kecamatan Gresik Kabupaten Gresik. 
JPPM (Jurnal Pendidikan dan Pemberdayaan Masyarakat), 7 (2), 2020 - 170

I Wayan Suryanto, Ni Made Erpia Ordani Astuti, I Gusti Ayu Agung Sinta Diarini

CARADDE: Jurnal Pengabdian Kepada Masyarakat, 2(2), 153-159.

https://doi.org/10.3196o/caradde.v2i2.283

Kurniawan, R. (2018). Pengaruh penerapan model pembelajaran teaching factory 6 langkah

(TF-6M) dan prestasi belajar kewirausahaan terhadap minat wirausaha. Prosiding

Pendidikan Teknik Boga Busana, 13(1).

https://journal.uny.ac.id/index.php/ptbb/article/view/33491

Marini, C. K., \& Hamidah, S. (2014). Pengaruh self-efficacy, lingkungan keluarga, dan lingkungan sekolah terhadap minat berwirausaha siswa SMK jasa boga. Jurnal Pendidikan Vokasi, 4(2). https://doi.org/10.21831/jpv.v4i2.2545

Maulani, M., Yogha, S., \& Yulia, C. (2016). Manfaat hasil belajar makanan penutup (dessert) pada uji level siswa SMK Negeri 3 Cimahi. Media Pendidikan, Gizi, Dan Kuliner, 5(2). https://doi.org/10.17509/boga.v5i2.5174

Mulyatiningsih, E., Sugiyono, S., \& Purwanti, S. (2014). Pengembangan edupreneurship sekolah kejuruan. Universitas Negeri Yogyakarta.

Muttaqien, I. (2019). Pengembangan entrepreneurship pada program MA keterampilan melalui inovasi model pembelajaran teaching factory di MAN 2 Kulon Progo. Jurnal Pendidikan Madrasah, 4(2), 231-242.

Odell, M. R. L., Kennedy, T. J., \& Stocks, E. (2019). The impact of PBL as a STEM school reform model. Interdisciplinary Journal of Problem-Based Learning, 13(2). https://doi.org/10.7771/1541-5015.1846

Pamungkas, A., \& Fauziah, P. Y. (2014). Evaluasi program kewirausahaan bengkel pada kejar paket B di PKBM Tunas Bangsa Tugu Semarang. JPPM (Jurnal Pendidikan Dan Pemberdayaan Masyarakat)Jurnal Pendidikan Dan Pemberdayaan Masyarakat, 1(2), 136148. https://doi.org/10.21831/jppm.vii2.2684

Rizky, D. A. F., Marji, M., \& Tuwoso, T. (2018). Pengaruh dukungan industri terhadap keberhasilan siswa melaksanakan teaching factory. Jurnal Pendidikan: Teori, Penelitian, Dan Pengembangan, 3(6), 799-805.

Sari, N. M. A. T. (2013). Pengaruh pelatihan, sikap, intensi, dan modal terhadap perilaku berwirausaha pada peserta program mahasiswa wirausaha. Ekuitas: Jurnal Pendidikan Ekonomi, 1(1).

Sudjana, N. (2002). Penilaian hasil proses belajar mengajar. PT Remaja Rosdakarya.

Suryanto, I. W., Astuti, N. M. E. O., \& Diarini, I. G. A. A. S. (2019). Development of project based learning model based on lesson study to improve interest of entrepreneurship, learning outcomes, and creativity of students. International Journal of Multidisciplinary Educational Research, 8(8 (7)).

Tahirs, J. P., \& Rambulangi, A. C. (2020). Menumbuhkan minat berwirausaha melalui pelatihan kewirausahaan bagi siswa smk. Community Development Journal: Jurnal Pengabdian Masyarakat, 1(2), 125-129. https://doi.org/10.31004/cdj.vii2.741

Tentama, F., \& Jayanti, H. D. (2019). Self-concept, perception of the learning environment and employability: A study of vocational high school students in Prambanan Yogyakarta, Indonesia. Humanities \& Social Sciences Reviews, 7(1), 433-440.

Utomo, H. (2015). Menumbuhkan minat kewirausahaan sosial. Among Makarti, 7(2). https://doi.org/10.52353/ama.v7i2.99

Virtue, E. E., \& Hinnant-Crawford, B. N. (2019). "We're doing things that are meaningful": Student Perspectives of Project-based Learning Across the Disciplines. Interdisciplinary Journal of Problem-Based Learning, 13(2). https://doi.org/10.7771/1541-5015.1809

Wijayanto, A., \& Prasetyo, I. (2018). Evaluasi program pendidikan kewirausahaan masyarakat. JPPM (Jurnal Pendidikan Dan Pemberdayaan Masyarakat), 5(2), 96-107. 
JPPM (Jurnal Pendidikan dan Pemberdayaan Masyarakat), 7 (2), 2020 - 171

I Wayan Suryanto, Ni Made Erpia Ordani Astuti, I Gusti Ayu Agung Sinta Diarini

https://doi.org/10.21831/jppm.v5i2.14999

Zainualdin, A., Abdullah, A., Kamarudin, H. S., Wan Yusuff, W. Y., \& Zainuddin, S. N. K. (2019).

Role of self-efficacy in improving the lives of youth in public housing. Humanities $\mathcal{E}$

Social Sciences Reviews, 7(2), 407-414. https://doi.org/10.18510/hssr.2019.7248 